\title{
Assessment of Growth Traits of Casuarina Clones at Diverse Sites in Karnataka
}

\author{
N. L. Deepthi Dechamma ${ }^{1 *}$, Ramakrishna Hegde ${ }^{1}$, V. Maheswarappa ${ }^{1}$, \\ Ganapathi $^{1}$, M. Varghese ${ }^{2}$, N. Ravi ${ }^{3}$ and A. Nicodemus ${ }^{4}$ \\ ${ }^{1}$ University of Agricultural and Horticultural Sciences, Shivamogga, Karnataka, India \\ ${ }^{2}$ ITC $R$ and D centre, ${ }^{3}$ Institute of Wood Science and Technology, Peenya, Bangalore, India \\ ${ }^{4}$ Institute of Genetics and Tree Breeding, Coimbatore, India \\ *Corresponding author
}

\section{A B S T R A C T}

\begin{tabular}{l} 
K e y w o r d s \\
$\begin{array}{l}\text { Casuarina, Site- } \\
\text { specific, Clonal } \\
\text { trial, Quantitative } \\
\text { and Qualitative }\end{array}$ \\
\hline Article Info \\
$\begin{array}{l}\text { Accepted: } \\
\text { 12 October } 2020 \\
\text { Available Online: } \\
10 \text { November } 2020\end{array}$ \\
\hline
\end{tabular}

Plantation forestry in India is playing a crucial role in meeting the wood requirement of the country. The productivity of plantations can be enhanced through the selection and deployment of site-specific clones with desirable traits and suitable silvicultural practices. Among the different fast-growing species, Casuarinas are preferred for environmental and commercial planting since the species have the adaptability to a wide range of climatic and edaphic conditions and has also gained importance as major pulpwood species. Sitespecific clones can be recommended for particular end uses by assessment of clonal trials. Thus, the present study was conducted to assess the growth performance of Casuarina clones in clonal trials located at Kunchenahally and Sindigere of Karnataka. There was a significant difference in quantitative and qualitative growth traits among the clones. $\mathrm{CH}-10$ showed better growth performance at Kunchenahally, whereas $\mathrm{CH}-4$ performed better at Sindigere site, respectively. Clone $\mathrm{CH}-4$ exhibited better growth performance among all the clones across the two sites.

\section{Introduction}

Forests are a rich source of energy, housing, timber, fuelwood, Non-Timber Forest Products and other goods and services. Demand for forest products and services in the country are increasing with rapid economic growth, industrialization and increase in population. In recent decades, wood has become one of the vital forest products and it is an important raw material for forest-based industries. Due to the low productivity of Indian forests, wood based papermills in India continues to face challenges with forest based raw material. The strategy adopted by the industry to meet the ever growing demand for wood on a sustainable basis is to obtain wood from social and farm forestry plantations (Kulkarni, 2013).

Plantation forests are renewable natural resources that play a crucial role to bridge the gap between the demand and supply of wood 
or other forest products. Most of the land available for plantations in tropics generally has soils with low fertility and soil degradation if subjected to poor management practices. Hence productivity of plantation on a sustainable basis is important. The productivity of plantation forests can be enhanced sustainably through appropriate tree improvement activities along with suitable silvicultural practises. In the recent years, planting of appropriate clones having desirable traits in favourable conditions along with intensive silvicultural practises found to increase the productivity and many wood based industries are adhering to the establishment of clonal plantations to meet their wood requirement (Hegde et al., 2009). According to FAO, nearly 45 per cent of India's forest plantations are fast-growing, short-rotation species (Prasad et al., 2009). Due to the rapid growth performance, nitrogen fixing ability and adaptability to wide variety of soil and climatic conditions including moisture and nutrient limited conditions Casuarina is preferred choice for commercial and environmental planting.

Casuarinas are widely planted in the tropics, subtropics and Mediterranean countries. Among the 96 species of trees and shrubs in the family Casuarinaceae, Casuarina equisetifolia has gained much attention due to its multiple end-uses and recently $C$. junghuhniana is also gaining momentum because of its use and adaptability (Turnbull, 1990).

C. equisetifolia was originally planted in Karwar during 1868-1869 (Kaikini, 1937) and in Nilgiris of the then Madras Presidency followed by Chengalpet and South Arcot districts of Tamil Nadu state (Gurumurthi and Subramanian, 1998). Nicodemus (2009) estimated that about 500,000 ha are planted with Casuarina in the coastal states of Andhra Pradesh, Orissa, Tamil Nadu and the Union
Territory of Puducherry. Casuarina junghuhniana has been introduced successfully to some countries in Africa including Kenya, Uganda and Tanzania and is increasingly being planted as an agroforestry tree (Mwihomeke et al., 2002). It is an important plantation species in India (Varghese et al., 2010).

Systematic and long-term breeding programmes for Casuarina equisetifolia and C. junghuhniana have been implemented in India since 1995. Genetically improved seeds and field-tested clones derived from broadbased international germplasm of these programmes have been deployed in commercial plantations which substantially increased wood production. Interspecific hybrids of $C$. equisetifolia and $C$. junghuhniana have shown faster growth and better stem straightness and disease resistance than the parent species in South India (Nicodemus et al., 2011). The relative performance of these hybrids differs when they are grown in different environments, because of the possible presence of genotype $x$ environment interaction. The information on these interactions can be utilized for identifying site-specific clones which are superior in one or more desirable combination of traits. The plantations established with these sites specific-clones will have the potential to increase the productivity and value of plantations. Hence, selection and deployment of appropriate genotype for a particular site are crucial in the modern plantation programmes.

With an object of enhancing pulpwood productivity of plantations clones of different selections and hybrids in Casuarina were introduced to Karnataka by Mysore Paper Mills, Bhadravathi and Karnataka Forest Development Corporation. However, the growth performance of these clones was not assessed at different sites. Thus, in the present 
study growth performance of Casuarina clones was assessed under diverse sites in Karnataka.

\section{Materials and Methods}

The present study was carried out in Casuarina clonal trials located at Kunchenahally, Shivamogga established by Mysore Paper Mills, Bhadravathi and clonal trial at Sindigere, Chikkamagaluru which was established by Karnataka Forest Development Corporation (Table 1; Fig. 1).

\section{Genetic material}

The genetic material used in this study were Casuarina hybrid clones $\mathrm{CH}-1, \mathrm{CH}-2, \mathrm{CH}-4$, $\mathrm{CH}-5, \mathrm{CH}-10$ and CJ-9 developed by the Institute of Forest Genetics and Tree Breeding, Coimbatore. Of these, $\mathrm{CH}-1, \mathrm{CH}-2$, $\mathrm{CH}-4, \mathrm{CH}-5, \mathrm{CH}-10$ and $\mathrm{CJ}-9$ were planted at Kunchenahally, Shivamogga by Mysore paper mills, Bhadravathi (Fig. 2). CH-1, CH-2 and $\mathrm{CH}-4$ were planted at Sindigere, Chikkamagaluru by Karnataka Forest Development Corporation (Table 2; Fig. 2).

\section{Details of the experiment}

The planting design followed for the establishment of clonal trials in both the locations was Randomized Complete Block Design (RCBD) and the trials were established during 2017-18. The details of the experiments at each location are represented in Table 3.

\section{Observations}

At two years of age, all trees were measured for the total height, clear bole height $(\mathrm{CBH})$, diameter at breast height (DBH) was derived using girth at breast height data by the formula
$\mathrm{DBH}=\frac{G B H}{\pi}$

Individual tree volume was estimated by the following formula

$$
\text { Volume }\left(\mathrm{cm}^{3}\right)=\mathrm{BA} \times \text { height } \times \mathrm{F}
$$

Where,

$$
\begin{aligned}
& \mathrm{BA}\left(\mathrm{cm}^{2}\right)=\frac{\pi(\mathrm{DBH})^{2}}{4} \\
& \mathrm{~F}-\text { Form factor }(0.33)
\end{aligned}
$$

Each tree was scored subjectively for branch thickness following the criteria developed by Jayaraj et al., (1997) and details are tabulated in Table 4.

\section{Statistical analysis}

The statistical analysis of the data on growth traits in individual sites was done as per the RCBD procedures for Shivamogga site, ANOVA for the data from Chikkamagaluru was not carried out due to insufficient degrees of freedom for RCBD analysis.

Across site performance of clones which were common at two sites (Kunchenahally and Sindigere) were subjected to factorial analysis by taking location and clones as factors and interaction of location $\times$ clone as treatment combination using SPSS (Statistical Package for Social Studies) 16.0 software.

\section{Results and Discussion}

Evaluation of growth performance of clones can provide information on the growth difference among the clones and it's relationship with the possible adaptability in the region of introduction.

Most of the quantitative growth traits such as total height, $\mathrm{DBH}, \mathrm{CBH}$ and volume and qualitative trait such as branch thickness differed significantly among the clones. 


\section{Clonal performance at individual sites}

In Kunchenahally the growth performance of interspecific hybrids was better than the intraspecific hybrid CJ-9 (Table 5). Among the different clones except for tree height, Clone $\mathrm{CH}-10$ showed substantially higher growth in terms of DBH $(2.96 \mathrm{~cm}), \mathrm{CBH}$ $(1.33 \mathrm{~m})$ and volume $\left(915.62 \mathrm{~cm}^{3}\right)$ (Fig. 3). However, tree height was found to be maximum in $\mathrm{CH}-2(4.01 \mathrm{~m})$ which was on par with $\mathrm{CH}-10, \mathrm{CH}-4$ and $\mathrm{CH}-5$. Further, consistent lower performance of the intraspecific hybrid (CJ-9) observed for the parameters such as height $(3.39 \mathrm{~m}), \mathrm{DBH}$ $(2.23 \mathrm{~cm})$, and volume $\left(443.27 \mathrm{~cm}^{3}\right)$. In Sindigere among all the clones, $\mathrm{CH}-4$ showed better growth performance in terms of quantitative traits such as total height $(4.64 \mathrm{~m})$, DBH $(3.04 \mathrm{~cm}), \mathrm{CBH}(0.81 \mathrm{~m})$ and volume $\left(1159.22 \mathrm{~cm}^{3}\right)$ (Table 6) .

Branch thickness affects sawn timber quality and has important implications for utilization. Branches small in relation to stem at the point of origin is considered ideal branching character for pulpwood species (Jayaraj et al., 1997). Significant difference was observed between the clones for branch thickness and the majority of the clones in Kunchenahally had thick branches (Table 5). In Sindigere except $\mathrm{CH}-2$ other clones had thick branches, while $\mathrm{CH}-2$ had light branches with a score of 5.06 (Table 6).

Table.1 Location details of the clonal trials

\begin{tabular}{|c|l|c|c|}
\hline Sl. No & Details & \multicolumn{2}{|c|}{ Locations } \\
\cline { 3 - 4 } & & Shivamogga & Chikkamagaluru \\
\hline $\mathbf{1}$ & Latitude & $14^{\circ} 22^{\prime} 22.9^{\prime \prime} \mathrm{N}$ & $13^{\circ} 21^{\prime} 09^{\prime \prime} \mathrm{N}$ \\
\hline $\mathbf{2}$ & Longitude & $75^{\circ} 33^{\prime} 43.7^{\prime \prime} \mathrm{E}$ & $75^{\circ} 55^{\prime} 11 " \mathrm{E}$ \\
\hline $\mathbf{3}$ & Altitude(m) & 705 & 935 \\
\hline $\mathbf{4}$ & Mean annual rainfall $(\mathrm{mm})$ & 974 & 912 \\
\hline $\mathbf{5}$ & Mean maximum temperature $\left({ }^{\circ} \mathrm{C}\right)$ & 32.57 & 30.71 \\
\hline $\mathbf{6}$ & Mean minimum temperature $\left({ }^{\circ} \mathrm{C}\right)$ & 20.55 & 18.26 \\
\hline $\mathbf{7}$ & Soil type & Red gravelly soil & Red gravelly soil \\
\hline
\end{tabular}

Table.2 Details of the hybrid clones

\begin{tabular}{|c|c|c|c|}
\hline SI.No & Clones & Clone details & Location details \\
\hline 1 & $\mathrm{CH}-1$ & $\begin{array}{l}\text { Interspecific hybrid of C. equisetifolia } \times \\
\text { C. junghuhniana }\end{array}$ & $\begin{array}{l}\text { Kunchenahally, Shivamogga } \\
\text { Sindigere, Chikkamagalur }\end{array}$ \\
\hline 2 & $\mathrm{CH}-2$ & $\begin{array}{l}\text { Interspecific hybrid of C. equisetifolia } \times \\
\text { C. junghuhniana }\end{array}$ & $\begin{array}{l}\text { Kunchenahally, Shivamogga } \\
\text { Sindigere, Chikkamagaluru }\end{array}$ \\
\hline 3 & $\mathrm{CH}-4$ & $\begin{array}{l}\text { Interspecific hybrid of C. equisetifolia } \times \\
\text { C. junghuhniana }\end{array}$ & $\begin{array}{l}\text { Kunchenahally, Shivamogga } \\
\text { Sindigere, Chikkamagaluru }\end{array}$ \\
\hline 4 & $\mathrm{CH}-5$ & $\begin{array}{l}\text { Interspecific hybrid of } C \text {. equisetifolia } \times \\
\text { C. junghuhniana }\end{array}$ & Kunchenahally, Shivamogga \\
\hline 5 & $\mathrm{CH}-10$ & $\begin{array}{l}\text { Interspecific hybrid of } C \text {. equisetifolia } \times \\
\text { C. junghuhniana }\end{array}$ & Kunchenahally, Shivamogga \\
\hline 6 & CJ-9 & Intraspecific hybrid of $C$. junghuhniana & Kunchenahally, Shivamogga \\
\hline
\end{tabular}


Table.3 Details of the experiment of clonal trials

\begin{tabular}{|l|l|c|c|}
\hline Sl. & \multirow{2}{*}{ Details } & \multicolumn{2}{|c|}{ Locations } \\
\cline { 3 - 4 } No & & Kunchenahally & Sindigere \\
\hline $\mathbf{1}$ & No. of clones & 6 & 3 \\
\hline $\mathbf{2}$ & Total No. of ramets & 1080 & 660 \\
\hline $\mathbf{3}$ & Replications & 6 & 20 \\
\hline $\mathbf{4}$ & No. of ramets for each clone & 30 & \\
\hline $\mathbf{5}$ & Spacing & $2 \mathrm{~m} \times 1.75 \mathrm{~m}$ \\
\hline $\mathbf{5}$ & Design & \multicolumn{2}{|c|}{ RCBD } \\
\hline $\mathbf{6}$ & Year of establishment & 2017 \\
\hline
\end{tabular}

Table.4 Criteria for scoring of branch thickness

\begin{tabular}{|c|l|c|}
\hline Sl. No & \multicolumn{1}{|c|}{ Criteria } & Score \\
\hline 1 & Very heavy $>$ two branches with diameter $>1 / 3^{\text {rd }}$ of the main stem & 2 \\
\hline 2 & Heavy, two branches with diameter $>1 / 3^{\text {rd }}$ of the main stem & 5 \\
\hline 3 & Light, one branch with diameter $>1 / 3^{\text {rd }}$ of the main stem & 7 \\
\hline 4 & Very light, branch diameter $<$ or $=1 / 3^{\text {rd }}$ of the main stem & 10 \\
\hline
\end{tabular}

Table.5 Growth performance of different clones at Kunchenahally, Shivamogga

\begin{tabular}{|c|c|c|c|c|c|c|}
\hline $\begin{array}{l}\text { Sl. } \\
\text { No }\end{array}$ & Clones & Height (m) & $\begin{array}{c}\text { DBH } \\
(\mathbf{c m})\end{array}$ & $\begin{array}{c}\text { CBH } \\
(\mathbf{m})\end{array}$ & $\begin{array}{c}\text { Branch } \\
\text { thickness* }\end{array}$ & Volume $\left(\mathrm{cm}^{3}\right)$ \\
\hline 1 & $\mathrm{CH}-1$ & $3.64^{b}$ & $2.36^{\mathrm{ab}}$ & $1.11^{\mathrm{a}}$ & $3.53(1.88)^{b}$ & $533.31^{\mathrm{ab}}$ \\
\hline 2 & $\mathrm{CH}-2$ & $4.01^{\mathrm{c}}$ & $2.67^{c}$ & $1.30^{\mathrm{bc}}$ & $3.27(1.81)^{b}$ & $756.12^{c}$ \\
\hline 3 & $\mathrm{CH}-4$ & $3.97^{\mathrm{c}}$ & $2.60^{c}$ & $1.22^{\mathrm{b}}$ & $3.34(1.83)^{b}$ & $704.64^{c}$ \\
\hline 4 & CH-5 & $3.87^{b c}$ & $2.51^{b c}$ & $1.25^{\mathrm{bc}}$ & $3.02(1.74)^{a b}$ & $647.53^{b c}$ \\
\hline 5 & CJ-9 & $3.39^{\mathrm{a}}$ & $2.23^{\mathrm{a}}$ & $1.12^{\mathrm{a}}$ & $3.02(1.74)^{a b}$ & $443.27^{\mathrm{a}}$ \\
\hline 6 & $\mathrm{CH}-10$ & $4.00^{c}$ & $2.96^{\mathrm{d}}$ & $1.33^{\mathrm{c}}$ & $2.59(1.61)^{\mathrm{a}}$ & $915.62^{d}$ \\
\hline \multicolumn{2}{|c|}{$\operatorname{SEm}( \pm)$} & 0.80 & 0.07 & 0.03 & 0.05 & 45.14 \\
\hline \multicolumn{2}{|c|}{ CD (0.05) } & 0.23 & 0.21 & 0.09 & 0.16 & 131.49 \\
\hline
\end{tabular}

Figures with similar letters as superscript do not differ significantly, CD- Critical difference *Parenthetical values are square root transformed values

Table.6 Growth performance of different clones at Sindigere, Chikkamagaluru

\begin{tabular}{|c|c|c|c|c|c|c|}
\hline $\begin{array}{c}\text { SI. } \\
\text { No }\end{array}$ & Clones & $\begin{array}{c}\text { Height }(\mathbf{m}) \\
(\mathbf{m e a n} \pm \mathbf{S D})\end{array}$ & $\begin{array}{c}\text { DBH(cm) } \\
(\mathbf{m e a n} \pm \mathbf{S D})\end{array}$ & $\begin{array}{c}\text { CBH(m) } \\
(\mathbf{m e a n} \pm \text { SD) }\end{array}$ & $\begin{array}{c}\text { Branch thickness } \\
(\mathbf{m e a n} \pm \mathbf{S D})\end{array}$ & $\begin{array}{c}\left.\text { Volume }^{*} \mathbf{c m}^{\mathbf{3}}\right) \\
(\mathbf{m e a n} \pm \text { SD) }\end{array}$ \\
\hline $\mathbf{1}$ & $\mathrm{CH}-1$ & $4.28 \pm 0.08$ & $2.76 \pm 0.16$ & $0.76 \pm 0.06$ & $3.42(1.85) \pm 0.10$ & $864.49 \pm 99.87$ \\
\hline $\mathbf{2}$ & CH-2 & $3.97 \pm 0.10$ & $2.23 \pm 0.09$ & $0.69 \pm 0.09$ & $5.06(2.25) \pm 0.08$ & $516.51 \pm 43.16$ \\
\hline $\mathbf{3}$ & CH-4 & $4.64 \pm 0.16$ & $3.04 \pm 0.20$ & $0.81 \pm 0.15$ & $3.13(1.77) \pm 0.13$ & $1159.22 \pm 179.19$ \\
\hline Overall Mean & $\mathbf{4 . 3 0}$ & $\mathbf{2 . 6 8}$ & $\mathbf{0 . 7 5}$ & $\mathbf{3 . 8 4}(\mathbf{1 . 9 6})$ & $\mathbf{8 4 6 . 7 4}$ \\
\hline
\end{tabular}

*Parenthetical values are square root transformed values 
Table.7 Growth performance of Casuarina clones across the two sites

\begin{tabular}{|c|c|c|c|c|c|c|}
\hline $\begin{array}{l}\text { Sl. } \\
\text { No }\end{array}$ & Particulars & Height(m) & DBH (cm) & $\begin{array}{c}\text { CBH } \\
\text { (m) }\end{array}$ & $\begin{array}{l}\text { Branch } \\
\text { thickness }\end{array}$ & Volume $\left(\mathrm{cm}^{3}\right)$ \\
\hline \multicolumn{7}{|c|}{ Location } \\
\hline 1 & Kunchenahally & 3.88 & 2.56 & 1.21 & $3.24(1.80)^{*}$ & 678.97 \\
\hline 2 & Sindigere & 4.30 & 2.67 & 0.75 & $4.00(2.00)$ & 826.85 \\
\hline & $\operatorname{SEm}( \pm)$ & 0.04 & 0.05 & 0.02 & 0.03 & 35.28 \\
\hline & CD (0.05) & 0.13 & NS & 0.08 & 0.10 & 101.92 \\
\hline \multicolumn{7}{|c|}{ Clones } \\
\hline 1 & CH-1 & $3.94^{\mathrm{a}}$ & $2.56^{\mathrm{a}}$ & 0.94 & $3.45(1.86)^{\mathrm{a}}$ & $696.52^{\mathrm{a}}$ \\
\hline 2 & $\mathrm{CH}-2$ & $4.00^{\mathrm{a}}$ & $2.44^{\mathrm{a}}$ & 0.99 & $4.57(2.14)^{b}$ & $635.02^{\mathrm{a}}$ \\
\hline 3 & $\mathrm{CH}-4$ & $4.33^{\mathrm{b}}$ & $2.84^{\mathrm{b}}$ & 1.01 & $3.31(1.82)^{\mathrm{a}}$ & $927.20^{\mathrm{b}}$ \\
\hline & $\operatorname{SEm}( \pm)$ & 0.05 & 0.06 & $\mathbf{0 . 0 3}$ & 0.04 & 43.21 \\
\hline & CD (0.05) & 0.17 & 0.19 & NS & 0.12 & 124.82 \\
\hline \multicolumn{7}{|c|}{ Location x clone } \\
\hline 1 & Kunchenahally x CH-1 & $3.61^{\mathrm{a}}$ & $2.38^{\mathrm{ab}}$ & $1.12^{\mathrm{b}}$ & $3.31(1.82)^{\mathrm{a}}$ & $543.68^{\mathrm{a}}$ \\
\hline 2 & Kunchenahally x CH-2 & $4.02^{c}$ & $2.66^{\mathrm{b}}$ & $1.30^{\mathrm{c}}$ & $3.09(1.76)^{\mathrm{a}}$ & $757.48^{b}$ \\
\hline 3 & Kunchenahally x CH-4 & $4.02^{c}$ & $2.64^{\mathrm{b}}$ & $1.22^{\mathrm{bc}}$ & $3.31(1.82)^{\mathrm{a}}$ & $735.76^{b}$ \\
\hline 4 & Sindigere x CH-1 & $4.28^{\mathrm{b}}$ & $2.76^{\mathrm{b}}$ & $0.76^{\mathrm{a}}$ & $3.61(1.90)^{\mathrm{a}}$ & $849.35^{b}$ \\
\hline 5 & Sindigere $\mathrm{x} C \mathrm{CH}-2$ & $3.97^{\mathrm{c}}$ & $2.22^{\mathrm{a}}$ & $0.69^{\mathrm{a}}$ & $5.24(2.29)^{b}$ & $512.57^{\mathrm{a}}$ \\
\hline 6 & Sindigere $\mathrm{x}$ CH-4 & $4.64^{\mathrm{d}}$ & $3.03^{\mathrm{c}}$ & $0.80^{\mathrm{a}}$ & $3.31(1.82)^{\mathrm{a}}$ & $1118.64^{c}$ \\
\hline \multicolumn{2}{|r|}{$\operatorname{SEm}( \pm)$} & 0.08 & 0.09 & 0.04 & 0.06 & 61.12 \\
\hline & CD (0.05) & 0.24 & 0.27 & 0.14 & 0.17 & 176.53 \\
\hline
\end{tabular}

*Parenthetical values are square root transformed values NS - Non Significant

Fig.1 Overview of experimental plots at different location
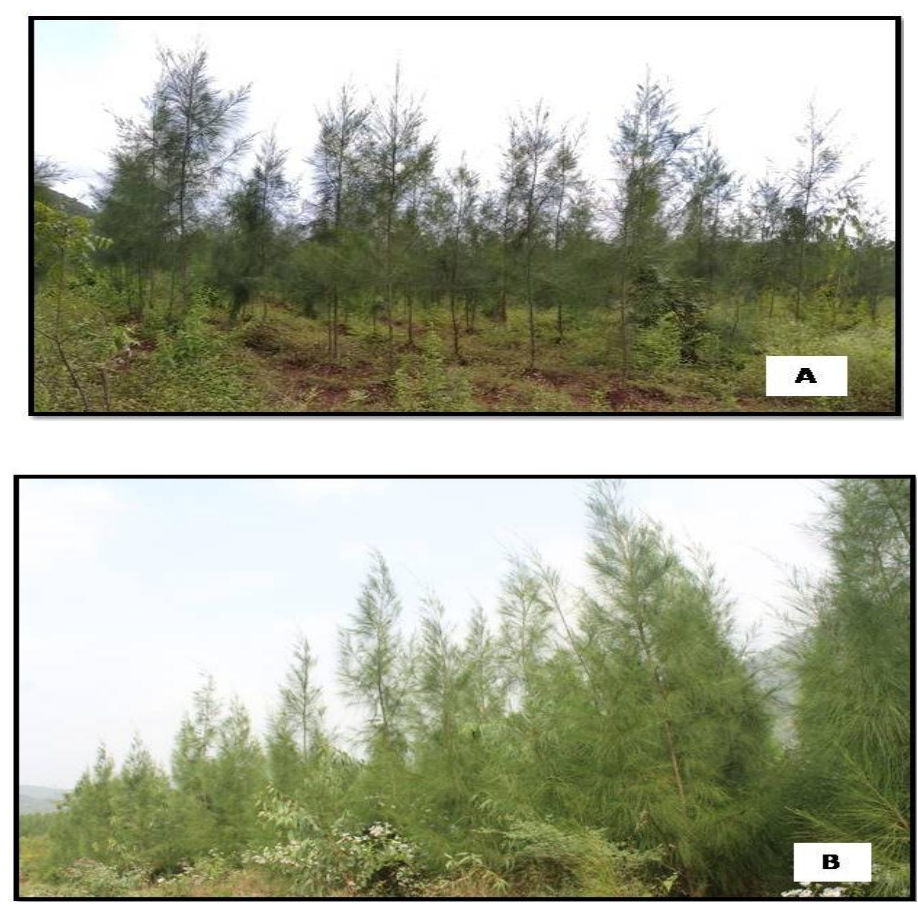
Fig.2 Different clones at Kunchenahally, Shivamogga

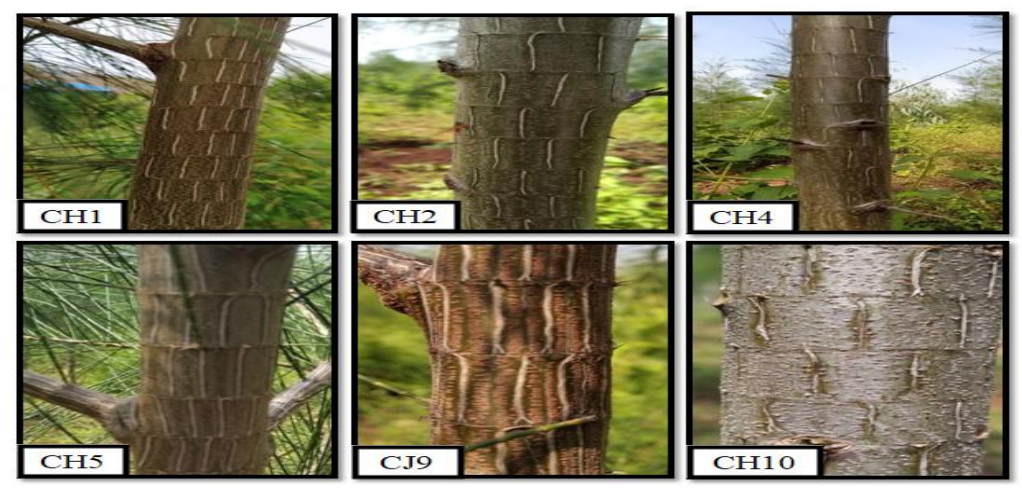

Fig.3 Different clones at Sindigere, Chikkamagaluru
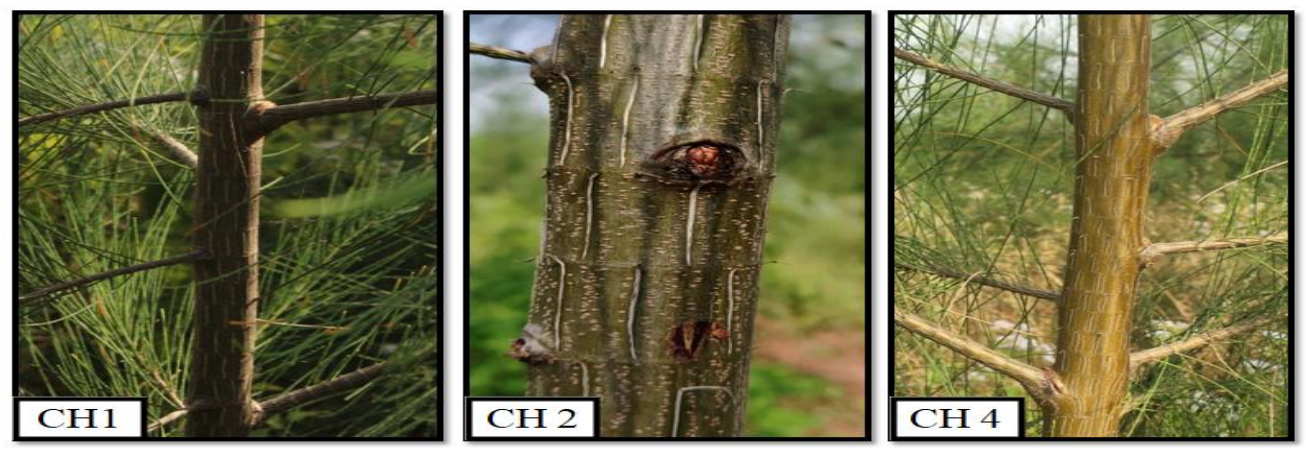

\section{Across site growth performance of clones}

Existence of significant difference between the sites, clones and significant site $\times$ clone interaction for growth parameters was evident in the study (Table 7). Growth performance in terms of height $(4.3 \mathrm{~m}), \mathrm{DBH}(2.67 \mathrm{~cm})$ and volume $\left(826.85 \mathrm{~cm}^{3}\right)$ was better in Sindigere, whereas Kunchenahally was better in branch thickness (3.24) and clear bole height (1.21 $\mathrm{m})$.

Significant difference was observed among the clones for all the growth traits except $\mathrm{CBH}$. The performance of clone $\mathrm{CH}-4$ was superior over other clones for all the traits such as height $(4.33 \mathrm{~m}), \mathrm{DBH}(2.84 \mathrm{~cm})$, $\mathrm{CBH}(1.01 \mathrm{~m})$ and volume $\left(927.20 \mathrm{~cm}^{3}\right)$ except branch thickness for which $\mathrm{CH} 2$ recorded the maximum score of 4.57(Table 7).
Significant site $\times$ clone interaction effects were found in most studied traits, i.e., the most promising clones were not the same at two sites. Among the two sites, in Kunchenahally $\mathrm{CH}-2$ exhibited the maximum values for quantitative traits viz., height (4.02 $\mathrm{m}), \mathrm{DBH}(2.66 \mathrm{~cm}), \mathrm{CBH}(1.30 \mathrm{~m})$ and volume $\left(757.48 \mathrm{~cm}^{3}\right)$ which was on par with $\mathrm{CH}-4$. In Sindigere $\mathrm{CH}-4$ recorded the highest values for all quantitative traits such as height $(4.64 \mathrm{~m}), \mathrm{DBH}(3.03 \mathrm{~cm}), \mathrm{CBH}(0.80 \mathrm{~m})$ and volume $\left(1118.64 \mathrm{~cm}^{3}\right)$. The average data on height, $\mathrm{DBH}$ and volume indicated that $\mathrm{CH}-4$ performed well in two sites, whereas $\mathrm{CH}-1$ exhibited poor growth in Kunchenahally, while in Sindigere $\mathrm{CH}-2$ exhibited considerable poor growth (Table 7).

Increasing wood production through the improvement of growth is often overlooked through some of the characteristics such as 
total height and DBH that are usually highly inherited (Longman, 1993). Understanding the clonal variations and their responses to the varying environment result in the higher yield and site-specific clonal recommendations.

Relatively fast growth shown by interspecific clones indicates their potential to increase wood production. In the present study, $\mathrm{CH}-10$ outperformed the CJ-9 at Kunchenahally as the interspecific hybrids possess the desirable combination of parental characters and can perform well in comparison with intraspecific hybrids as reported in the earlier studies with interspecific hybrid families (Kannan et al., 2012; Nicodemus et al., 2013).

Branching attributes of the trees have important implications for utilization. $C$. junghuhniana is often planted for windbreaks in agroforestry and branching characteristics are important in this application as they influence the stability of trees in windstorms. Significant difference was observed between the clones for branch thickness and the majority of the clones had thick branches which were in accordance with the observations made by Leuchanimitchit et al., (2017)

The higher performance of the clones in Sindigere can be attributed to the more favourable environmental factors at Sindigere. The higher temperature coupled with higher relative humidity has contributed to the better performance of the clones than in Kunchenahally. Kannan et al., (2014) conducted a similar study where significantly high $G \times \mathrm{E}$ interactions was observed in the growth performance of hybrid clones in coastal and inland locations of Tamil Nadu. It was observed that between the two locations growth was considerably higher in the coastal site with climatic condition such as rainfall similar to the locations in the present study.

\section{Acknowledgement}

The authors sincerely thank the University of Agricultural and Horticultural Sciences, Shivamogga for this opportunity. We thank the College of Forestry, Ponnampet for providing technical support and suggestions during the research period. The authors thank managing director and field staffs of Karnataka Forest Development Corporation and Mysore paper mills for their support during the field work.

\section{References}

Gurumurthi, K., and Subramanian, K. 1998. Casuarina - Favourite tree of farmers in peninsular, India. Proceedings of National Seminar on Popularising Theme Trees among People including Rural and Urban Forest Industry. 1998, ICFRE, Dehra Dun, India, pp. 83-88.

Hegde, R., Sreekantaiah, G.N. and Karki, M.R.,2009. Field manual on Clonal Forestry. pp.29-31.

Jayaraj, R.S.C., Gurumurthi, K., Hegde, R., Warrier, K.C.S., Kumar, A.K.G. and Vivekanandan, K., 1997. Assessment of clonal trials of Eucalyptus. Institute of Forest Genetics and Tree Breeding, Coimbatore, Tamil Nadu, India. pp. 4850.

Kaikini, D.S., 1937. Note on Casuarina equisetifolia plantation in Karwar. Indian For. 63(10):661-668.

Kannan, K., Nicodemus, A. and Jayaraj, R.S.C.,2012. Clonal variation in the adventitious rooting behaviour of Casuarina equisetifolia, C. junghuhniana and their interspecific hybrids. Advances in Casuarina Research in India. Proceedings of second National Seminar on Casuarinas. Institute of Forest Genetics and Tree Breeding, Coimbatore, Tamil Nadu, India. pp. 271-274.

Kulkarni, H.D., 2013. Pulp and paper industry raw material scenario-ITC plantation a case study. IIPTA. 25(1):79-90. 
Leuchanimitchit, P., Luangviriyasaeng, V., Laosakul, S., Pinyopusarerk, K. AND Bush, D., 2017. Genetic parameter estimates for growth, stem- form and branching traits of Casuarina jumghuhniana clones grown in Thailand. For. Eco. Mant., 404: 251-257.

Longman, K.A., 1993. Tropical trees: propagation and planting manuals. Volume 1. Rooting cuttings of tropical trees. Commonwealth Science Council. pp. 135.

Mwihomeke, T. S.T., Mugasha, A.G., Chamshama, S.A.O., Mgangamundo, M.A., Kumburu, O.C. and Lupala, Z,2002. Early performance of Casuarina junghuhniana provenances/land races at Lushoto, Tanzania. The Southern African Forestry Journal. 194(1):7-14.

Nicodemus, A., 2009. Casuarina - A Guide for Cultivation. Institute of Forest Genetics and Tree Breeding (Indian Council of Forestry Research and Education) Coimbatore, India, pp. 16.

Nicodemus, A., Kannan, K., Sagariya, Y.C., Pauldasan, A., Karthikeyan, A. and Singh, B.G., 2013. Variation in blisterbark disease incidence among Casuarina equisetifolia, C. junghuhniana and their interspecific hybrids and its implications for disease resistance breeding. Proceedings of National Seminar on Forest Health Management. IFGTB, Tamil Nadu (India) pp. 552-563.

Nicodemus, A., Sagariya, C.Y., Kannan, K.,
Rangarajan, R.M.A. and Singh, B.G., 2011. Production of inter-provenance and inter-specific hybrids of Casuarina equisetifolia and $C$. junghuhniana and their early evaluation for growth and form traits. Proceedings of fourth International Casuarina Workshop- Improving Smallholder Livelihoods through Improved Casuarina Productivity, 2010, Haikou, Marc (China), pp. 5-10.

Prasad, J.V.N.S., Gangaiah, B., Kundu, S., Korwar, G.R., Venkateswarlu, B. and Singh, V.P., 2009. Potential of short rotation woody crops for pulp fiber production from arable lands in India. Ind. J. Agron. 54: 380-394.

Turnbull, J.W., 1990. Taxonomy and genetic variation in casuarinas. Advances in casuarina research and utilization. Proceedings of second International Casuarina workshop, 15-20,January, 1990,Desert Development Center, American University, Cairo(Egypt), pp. 1-11.

Varghese, M., Kamalakannan, R., Nicodemus, A. and Pinyopusarerk, K., 2010. Fertility and progeny performance in seedling seed orchards of Casuarina equisetifolia and C. junghuhniana. Proceeding fourth International Casuarina WorkshopImproving Smallholder Livelihoods through Improved Casuarina Productivity, 2010, Haikou, Marc, (China), pp.21-25.

\section{How to cite this article:}

Deepthi Dechamma, N. L., Ramakrishna Hegde, V. Maheswarappa, Ganapathi, M. Varghese, N. Ravi and Nicodemus, A. 2020. Assessment of Growth Traits of Casuarina Clones at Diverse Sites in Karnataka. Int.J.Curr.Microbiol.App.Sci. 9(11): 1348-1356.

doi: https://doi.org/10.20546/ijcmas.2020.911.159 